\title{
Commodity Futures and Spot Exchanges
}

\author{
Jyothi, K.C.* \\ * Research Scholar, DOS in Economics, Kuvempu University, Shankaraghatta - 577 451, Shimoga
}

\begin{abstract}
Commodity Futures and Spot Exchanges are a part of the larger securities market worldwide. In India, the market is in the developmental stage. However, since the opening up of the market in March 1995, growth has been exponential. The Forward Markets Commission has been regulating the market. Three National Exchanges and 21 other exchanges are functioning in the country. The National Exchanges with online transparent trading and settlement systems account for $97.2 \%$ of trading. There are over 20000 terminals all over the country enabling easier access to the stake holders. The turnover in the market has risen from Rs. 6530.74 lakh crores in 2002-03, to Rs. 3316206.92 lakh crores in 2008-09, representing an annualized growth of $830 \%$. This paper takes a peek into the working of the commodities futures market in general and agricultural commodities market in particular. It tries to analyze the purpose, role and impact of agricultural commodity futures on the price of these commodities, particularly in the light of the general perception that the futures market is one of the causes of price rise. The study compares the impact of ban in futures trading on certain agricultural commodities on prices.

The study reveals that the impact, if at all, is only marginal. The reasons for the rise in prices have been found to be factors other than futures trading. The study concludes with a suggestion to educate the stake holders to enable healthy growth of the futures market.
\end{abstract}

\section{Introduction}

The stock markets are a fine example of human innovation, ingenuity \& imagination. They are the wealth creators \& a barometer of the financial health of a nation. So much so, that even communist China has embraced the much hated capitalistic icon - the speculation riddled stock market. While the stock market has a long history, the commodity market began in $1875 \&$ has a chequered history. It faced many hurdles in the form of prohibitions from time to time. The commodities market was subject to manipulation by speculators, lack of regulatory mechanism \& transparency. This had an adverse impact on the prices of commodity, particularly of common consumption like sugar, wheat, dhal, etc., leading to inflation \& consequent discontent among the people.

Various comities were setup from time to time to regulate the commodities market. The Dantawala committee, the Kusro committee, the Kambra committee \& more recently the Abijith Sen committee were set up to go into the complexities of the future commodities market $\&$ suggest measures for the smooth $\&$ efficient functioning of the futures market. These measures got further impetus with the opening up of the economy in 1990 under the liberation, privatization \& globalization process. As a result of these measures the commodity futures market has expanded exponentially with over 22 recognized commodity market, over 20000 terminals spread all over the country \& a turn over of 33.16 lakh crores in 2008-09. While the number of commodities have been restricted \& futures trading banned in certain commodities from time to time due to the fear of artificial escalation in prices of essential \& sensitive commodities, the Indian commodity futures and spot markets are bound for takeoff, with the Forward Markets Commission becoming the regulator and the spread of information and communication technology bringing the farmers, processors, arbitrators and consumers to a single platform. It is hoped that greater awareness among the stake holders, transparency and proper regulation will make these exchanges useful for price discovery, risk hedging and benefit all the stake holders.

\section{Review of Literature}

A number of studies have been conducted on the commodity future and spot exchange markets in India. Some of these are enumerated below:

1. Narender L Ahuja (2006), India is among the top five producers of most of the commodities, in addition to being a major consumer of bullion and energy products. The market has made enormous progress after the government protection was removed from a number of commodities and market forces were allowed to play their road. Pricing and price risk management should be left to the market forces, rather then trying to achieve these through administrated price mechanisms.

2. Kolamkar DS (2003), the spot markets are largely controlled by the state government and there are restrictions on holding of stock, turnover and movement of goods. There are variations in the duties levied by 
the different state government. This impedes the commodity future market from reaching the market players outside the boundaries or zones.

3. Golakh C Nath and Thulasi Linga Reddy (2005), in India future trading in selected commodities has resulted in increase the prices of commodities like Urad. It also increase the volatilities in the spot market.

4. Romar Correa (2005), the impact of agriculture future on output and prices is not clear. It is not surprising that India's planning commission has not found systematic evidence to either support or prohibit it.

5. Mihor Dash and Souwmya (2006), casualty in commodity market can be used either to hedge or speculate price movements. If changes in spot prices drive changes in future prices, efficient hedging strategies can be formulated, whereas, if changes in future prices drive changes in spot prices, efficient speculation strategies can formulated. Further, causality can be used in forecasting commodity spot and future prices.

6. Kamara (1982), finds that the introduction of commodity futures trading generally reduced or at least did not increase the cash price volatility. Further, Singh (2000) investigated the hessian cash (spot) price variability, before and after the introduction of futures trading (1988-1997) in Indian markets using the multiplicative dummy variable model and concluded that futures trading had reduced the price volatility in the hessian cash market. However, Yang et at (2005) showed that an unexpected and unidirectional increase in futures trading volume drove up the cash price volatility.

7. Nitesh (2005), reveals that futures trading in soya oil futures was effective in reducing the seasonal price volatilities, but not the daily price volatilities in India.

8. Sahi (2006), finds that the nature of volatility did not change with the introduction of futures trading in wheat, turmeric, sugar, cotton, raw jute and soya oil. Nevertheless, a weak destabilizing effect of futures on spot prices was found in case of wheat and raw jute. Further, the results of granger causality tests indicated that the unexpected increase in futures activity in terms of rise in. volumes and open interest caused an increase in the cash price volatilities in all the commodities listed.

9. Nath and Reddy (2007), find that futures activity leads to price volatilities in the case of urad dal but not in the case of gram and wheat. Therefore, the study concludes that the belief that futures trading contributes to rise in inflation (WPI) appears to have no merit in the present context.

10. A study by the Indian Institute of Management, Bangalore (IIMB) in 2008 explains that changes in fundamentals (mainly from the supply side) along with government policies were causing higher post-futures price rise and the role of futures trading remained unclear. BC (2008) while analyzing the impact of futures trading on commodity prices found that out of 21 commodities, price volatility increased in 10 commodities, remained unchanged in two, and declined in 9, after the introduction of 13 futures trading. However, the committee could not find any strong conclusion on whether introduction of futures trade is associated with decrease or increase in spot price volatility. Looking at price growth and price volatility of top ten agricultural commodities consisting major future trade, it is not clear whether future trading contributes to price rise or price volatility.

\section{Objectives of the Study}

The objective are the study are:

1. To find whether the commodity future market has a direct influence on the prices of agriculture commodities.

2. To explore, the extant of influence market manipulators make on the prices of agriculture commodities.

3. To find ways and means to make the agriculture commodity market transparent and vibrant.

\section{Hypotheses}

The hypothesis for the study are

1. There is no significant influence of future trading on the prices of agriculture commodities.

2. The prices of agriculture commodities rise due to reasons other than future trading.

3. Future trading if transparent will benefit the producers, the processors aid consumers.

\section{Methodology}

Empirical evidence through the collection of data from the three major stock exchanges has been made. The data collected before and after the ban of certain agriculture commodities have been compared. By comparing the rate of change with the general wholesale price index inference has been drawn.

\section{Sampling design}

The major three National Level Exchanges in India namely, NMCE, NCDEX and MCX were selected for the study. Due to a large number of commodities traded in these exchanges and the importance they are gaining lately, selecting these three exchanges for the study was necessary.

\section{Finding of the Study}


1. There are three national exchanges- NCDEX, MCX and NMCE account for $97.2 \%$ of the total future trade in the country. The other 21 recognized stock exchanges account for a mere $2.8 \%$.

2. The network of futures trading is spreading fast with over 20 thousand terminals in 800 cities all over the country.

3. The total value of the turnover in the futures market was 66530.74 lakh crores in 2002-03 and 3316206.92 lakh crores in 2008-09.

4. The volume of agriculture commodities is very small in volume. It was 3.90 lakh crores in 2004-05 and 9.41 lakh crores in 2007-08, the percentage of agriculture commodity turnover has declined in percentage terms from $68.18 \%$ in $2004-05$ to $23.15 \%$ in $2007-08$.

5. Option trading has been presently prohibited.

Select commodities and there commencement of future trading

\begin{tabular}{|l|l|}
\hline Commodity & Date of commencement of futures \\
\hline Wheat & $6^{\text {th }}$ July, 2004 \\
\hline Chana & $12^{\text {th }}$ April 2004 \\
\hline Tur & $8^{\text {th }}$ April 2005 \\
\hline Urad & $26^{\text {th }}$ July, 2004 \\
\hline Sugar & $17^{\text {th }}$ July, 2004 \\
\hline Guar & $10^{\text {th }}$ April 2004 \\
\hline
\end{tabular}

Volume \& Value of Trading in Major Agri-commodities (2004-05 to 2007-08) (Volume of Trading - in Lakh Tonnes, Value - in Rs. crores)

\begin{tabular}{|c|c|c|c|c|c|c|c|c|c|}
\hline \multirow{2}{*}{$\begin{array}{l}\text { Sl. } \\
\text { No. }\end{array}$} & \multirow{2}{*}{$\begin{array}{l}\text { Name of the } \\
\text { commodity }\end{array}$} & \multicolumn{2}{|c|}{ 2004-05 } & \multicolumn{2}{|c|}{ 2005-06 } & \multicolumn{2}{|c|}{ 2006-07 } & \multicolumn{2}{|c|}{ 2007-08 } \\
\hline & & Volume & Value & Volume & Value & Volume & Value & Volume & Value \\
\hline \multirow[t]{2}{*}{ I. } & \multicolumn{9}{|c|}{ Agricultural Commodities } \\
\hline & \multicolumn{9}{|c|}{ Major agricultural commodities } \\
\hline 1 & Guar seed & 799.10 & 129522.98 & 1902.04 & 330439.50 & 1609.96 & 324881.42 & 670.48 & 123752.55 \\
\hline 2 & Chana / gram & 108.42 & 16754.59 & 1240.27 & 234774.10 & 1191.99 & 306794.19 & 381.48 & 93517.27 \\
\hline 3 & Soy oil & 249.58 & 101527.66 & 297.69 & 110229.65 & 401.51 & 176667.56 & 448.29 & 241588.02 \\
\hline 4 & Pepper & 11.63 & 8334.28 & 11.56 & 8029.83 & 76.26 & 90727.61 & 71.97 & 105323.74 \\
\hline 5 & $\begin{array}{l}\text { Jeera (cumin } \\
\text { seed) }\end{array}$ & 3.61 & 2945.06 & 17.77 & 118822.97 & 69.15 & 67476.78 & 60.73 & 72929.87 \\
\hline 6 & Urad & 65.23 & 10277.49 & 769.81 & 196904.49 & 164.65 & 53546.13 & - & - \\
\hline 7 & Menthe oil & 0.00 & 0.00 & 6.66 & 41533.49 & 8.56 & 52103.60 & 1.95 & 10051.68 \\
\hline 8 & Chillis & 0.23 & 60.50 & 24.28 & 7487.16 & 71.87 & 38651.43 & 25.91 & 12461.14 \\
\hline 9 & Soy seed & 74.48 & 9797.15 & 111.53 & 13859.67 & 189.16 & 26238.80 & 326.05 & 60746.07 \\
\hline 10 & Mustard seed & 107.42 & 19464.35 & 94.93 & 16631.52 & 114.61 & 22332.37 & 362.55 & 88233.78 \\
\hline 11 & Wheat & 36.95 & 2839.31 & 194.26 & 15970.18 & 235.07 & 22179.56 & 0.15 & 15.02 \\
\hline 12 & Potato & 0.00 & 0.00 & 8.01 & 579.17 & 256.53 & 15004.25 & 90.62 & 5525.92 \\
\hline 13 & Tumeric & 4.49 & 1111.09 & 15.97 & 3943.46 & 65.00 & 14817.62 & 109.24 & 28147.52 \\
\hline 14 & Castro seed & 82.21 & 14327.34 & 73.17 & 11713.12 & 80.75 & 14638.78 & 87.32 & 19572.71 \\
\hline 15 & Sugar & 41.01 & 7737.30 & 139.99 & 26759.68 & 75.34 & 13690.22 & 177.06 & 24365.09 \\
\hline 16 & Guar gum & 28.83 & 13412.08 & 79.67 & 36986.05 & 25.88 & 13132.09 & 10.80 & 4940.50 \\
\hline 17 & Gur & 68.14 & 7891.49 & 107.08 & 16441.32 & 81.84 & 11052.30 & 50.69 & 6242.82 \\
\hline 18 & $\mathrm{Tr}$ & 0.37 & 60.47 & 231.19 & 41548.02 & 53.91 & 10697.27 & - & - \\
\hline 19 & Kapas & 192.05 & 33317.12 & 182.78 & 30808.44 & 42.28 & 8256.56 & 41.47 & 9789.33 \\
\hline 20 & Rubber & 4.80 & 2744.71 & 7.05 & 4830.48 & 8.45 & 8166.79 & 5.65 & 5119.94 \\
\hline 21 & Cardamom & 0.12 & 420.56 & 0.11 & 292.72 & 1.64 & 7427.29 & 0.74 & 4072.0 \\
\hline 22 & Maize & 2.03 & 109.69 & 16.98 & 927.23 & 65.19 & 4921.02 & 29.21 & 2300.70 \\
\hline 23 & Raw jute & 28.71 & 3747.53 & 39.07 & 5471.97 & 10.66 & 1426.49 & 16.38 & 2164.88 \\
\hline 24 & Rice & 2.40 & 396.71 & 9.33 & 1471.05 & 2.36 & 456.03 & - & - \\
\hline (A) & Total of above & 1911.80 & 386799.46 & 5581.20 & 1169455.27 & 4902.62 & $\begin{array}{c}1305286.1 \\
6\end{array}$ & 2968.74 & 920860.59 \\
\hline (B) & $\begin{array}{l}\text { Other } \\
\text { agricultural } \\
\text { commodities }\end{array}$ & 27.58 & 3388.90 & 237.60 & 22771.60 & 121.30 & 1139.05 & 176.49 & 20500.48 \\
\hline $\begin{array}{c}\text { (A) } \\
+ \\
(\mathrm{B}) \\
\end{array}$ & $\begin{array}{l}\text { Total } \\
\text { agricultural } \\
\text { commodities }\end{array}$ & 1939.38 & 390188.4 & 5818.8 & 1192226.9 & 5023.92 & $\begin{array}{c}1317125.2 \\
1\end{array}$ & 3145.23 & 941361.07 \\
\hline II & $\begin{array}{l}\text { Bullion \& } \\
\text { metals }\end{array}$ & 2.72 & 179671.1 & 58.45 & 779398.35 & 190.88 & $\begin{array}{c}2128985.1 \\
8\end{array}$ & 451.92 & 2623666.79 \\
\hline III & Energy & 0 & 1900.14 & 908.96 & 181882.64 & 914.34 & 230711.92 & 1976.22 & 500942.14 \\
\hline IV & Plastics & 0 & 0 & 2.505 & 1614.16 & 0.15 & 104.36 & 0.04 & 19.48 \\
\hline & $\begin{array}{l}\text { Grand total (I to } \\
\text { IV) }\end{array}$ & 1942.1 & 571759.6 & 6788.71 & 2155122 & 6129.29 & $\begin{array}{c}3676926.6 \\
7\end{array}$ & 5573.41 & 4065989.47 \\
\hline
\end{tabular}


Annualized Trend Growth Rate and Volatility of WPI of Selected Agricultural Commodities in which Futures are traded

\begin{tabular}{|c|c|c|c|c|c|c|c|c|c|c|}
\hline \multirow{3}{*}{$\begin{array}{l}\text { Sl. } \\
\text { No. }\end{array}$} & \multirow{3}{*}{$\begin{array}{l}\text { Name of the } \\
\text { commodity }\end{array}$} & \multirow{3}{*}{$\begin{array}{c}\text { WPI } \\
\text { Weights } \\
(1993-94)\end{array}$} & \multicolumn{4}{|c|}{ Monthly data } & \multicolumn{4}{|c|}{ Weekly data } \\
\hline & & & \multicolumn{2}{|c|}{$\begin{array}{c}\text { WPI Trend } \\
\text { Growth Rate }(\%)\end{array}$} & \multicolumn{2}{|c|}{$\begin{array}{c}\text { WPI volatility } \\
(\%)\end{array}$} & \multicolumn{2}{|c|}{$\begin{array}{c}\text { WPI Trend } \\
\text { Growth Rate }(\%)\end{array}$} & \multicolumn{2}{|c|}{$\begin{array}{c}\text { WPI volatility } \\
(\%)\end{array}$} \\
\hline & & & $\begin{array}{c}\text { Pre- } \\
\text { futures }\end{array}$ & $\begin{array}{c}\text { Post- } \\
\text { future } \\
\text { s }\end{array}$ & $\begin{array}{c}\text { Pre- } \\
\text { futures }\end{array}$ & $\begin{array}{c}\text { Post- } \\
\text { futures }\end{array}$ & $\begin{array}{c}\text { Pre- } \\
\text { futures }\end{array}$ & $\begin{array}{l}\text { Post- } \\
\text { futures }\end{array}$ & $\begin{array}{c}\text { Pre- } \\
\text { futures }\end{array}$ & $\begin{array}{c}\text { Post- } \\
\text { futur } \\
\text { es }\end{array}$ \\
\hline 1 & Guar seed & - & - & - & - & - & - & - & - & - \\
\hline 2 & Chana / gram & 0.223650 & -9.2 & 20.9 & 10.6 & 11.3 & -9.1 & 20.8 & 9.2 & 9.7 \\
\hline 5 & Jeera (cumin seed) & 0.102880 & -5.0 & 8.1 & 12.9 & 16.1 & -5.0 & 8.8 & 17.7 & 17.7 \\
\hline 6 & Urad & 0.096190 & -7.9 & 32.9 & 9.0 & 15.7 & -7.7 & 32.7 & 10.9 & 18.4 \\
\hline 7 & Menthe oil & - & - & - & - & - & - & - & - & - \\
\hline 8 & Chillis & 0.188660 & -16.4 & 42.9 & 15.0 & 17.1 & -16.3 & 42.3 & 15.1 & 21.5 \\
\hline 9 & Soy seed & 0.446140 & 12.2 & -11.3 & 15.1 & 21.5 & 12.1 & -11.4 & 3.6 & 4.0 \\
\hline 14 & Castro seed & 0.085720 & 2.5 & -2.2 & 13.5 & 12.7 & 2.4 & -1.5 & 21.0 & 14.0 \\
\hline 15 & Sugar & 3.618830 & 1.2 & 3.2 & 7.7 & 7.6 & 1.3 & 3.0 & 5.9 & 6.0 \\
\hline 16 & Guar gum & - & - & - & - & - & - & - & - & - \\
\hline 17 & Gur & 0.059790 & 25.4 & -0.6 & 9.6 & 11.6 & 21.6 & -0.6 & 17.0 & 12.0 \\
\hline 18 & $\operatorname{Tr}$ & 0.134660 & 2.8 & 5.8 & 9.0 & 7.7 & 2.9 & 5.8 & 9.1 & 10.0 \\
\hline 19 & Kapas & 1.356740 & -21.7 & 5.2 & 12.9 & 10.6 & -21.4 & 5.2 & 9.5 & 15.9 \\
\hline 20 & Rubber & 0.150800 & 105 & 20.1 & 16.0 & 21.1 & 104 & 19.9 & 16.5 & 21.0 \\
\hline 21 & Cardamom & 0.024940 & -20.3 & 4.6 & 11.7 & 19.5 & -20.2 & 4.7 & 25.7 & 29.9 \\
\hline 22 & Maize & 0.185010 & -2.4 & 9.6 & 11.4 & 6.8 & -2.3 & 9.7 & 10.4 & 9.2 \\
\hline 23 & Raw jute & 0.108680 & -11.4 & 10.8 & 13.4 & 13.6 & -11.3 & 10.7 & 17.5 & 13.9 \\
\hline \multicolumn{2}{|c|}{ CPI-UNME } & & 3.44 & 5.70 & 1.51 & 1.69 & & & & \\
\hline
\end{tabular}

Ratio of highest to lowest monthly WPI during year

\begin{tabular}{|l|l|l|l|l|l|l|l|}
\hline & 2001 & 2002 & 2003 & 2004 & 2005 & 2006 & 2007 \\
\hline Wheat & 1.03 & 1.04 & 1.07 & 1.08 & 1.09 & 1.17 & 1.08 \\
\hline Urad & 1.17 & 1.10 & 1.08 & 1.09 & 1.42 & 1.44 & 1.34 \\
\hline Chana & 1.27 & 1.19 & 1.05 & 1.03 & 1.27 & 1.42 & 1.14 \\
\hline Chillies & 1.09 & 1.13 & 1.22 & 1.44 & 1.28 & 1.63 & 1.22 \\
\hline Raw rubber & 1.32 & 1.23 & 1.20 & 1.26 & 1.33 & 1.41 & 1.22 \\
\hline
\end{tabular}

Prices of urad and turA. Urad

Rs. Per $100 \mathrm{~kg}$

\begin{tabular}{|c|c|c|c|c|c|c|c|}
\hline \multirow{3}{*}{ Date } & \multicolumn{6}{|c|}{ Spot and future prices at NCDEX } & \multirow{3}{*}{$\begin{array}{c}\text { WPI } \\
(93-94=100)^{*}\end{array}$} \\
\hline & \multirow{2}{*}{ Spot } & \multicolumn{5}{|c|}{ Futures closing prices for contract expiring on } & \\
\hline & & 20-02-07 & 30-03-07 & 30-04-07 & 18-05-07 & 20-06-07 & \\
\hline 23-01-07 & 3550.70 & 3234.00 & 3145.00 & 3005.00 & 2939.00 & 2905.00 & $393.5(20-01-07)$ \\
\hline 23-02-07 & 3202.70 & & & & & & $398.9(24-02-07)$ \\
\hline 23-03-07 & 3235.00 & & & & & & $381.97(24-03-07)$ \\
\hline $23-04-07$ & 3060.00 & & & & & & $380.0(21-04-07)$ \\
\hline $23-05-07$ & 2575.00 & & & & & & $360.4(26-05-07)$ \\
\hline 23-06-07 & 2742.65 & & & & & & $363.7(23-06-07)$ \\
\hline $23-07-07$ & 2700.00 & & & & & & $362.4(21-07-07)$ \\
\hline 04-04-07 & 2553.20 & & & & & & \\
\hline
\end{tabular}


B. TurRs. Per $100 \mathrm{~kg}$

\begin{tabular}{|c|c|c|c|c|c|c|c|}
\hline \multirow{3}{*}{ Date } & \multicolumn{6}{|c|}{ Spot and future prices at NCDEX } & \multirow{3}{*}{$\begin{array}{c}\text { WPI } \\
(93-94=100)^{*}\end{array}$} \\
\hline & \multirow{2}{*}{ Spot } & \multicolumn{5}{|c|}{ Futures closing prices for contract expiring on } & \\
\hline & & 20-02-07 & 30-03-07 & 30-04-07 & 18-05-07 & $20-06-07$ & \\
\hline $23-01-07$ & 23378.20 & 2281.00 & 2477.00 & 2524.00 & 2563.00 & 2664.00 & $188.4(20-01-07)$ \\
\hline $23-02-07$ & 2244.00 & & & & & & $193.2(24-02-07)$ \\
\hline 23-03-07 & 2302.65 & & & & & & $190.0(24-03-07)$ \\
\hline $23-04-07$ & 2362.50 & & & & & & $195.6(21-04-07)$ \\
\hline $23-05-07$ & 2325.00 & & & & & & $196.6(26-05-07)$ \\
\hline 23-06-07 & 2490.00 & & & & & & $196.2(23-06-07)$ \\
\hline $23-07-07$ & 2669.40 & & & & & & $199.5(25-07-07)$ \\
\hline 04-04-07 & 2600.00 & & & & & & \\
\hline
\end{tabular}

Note: * Data relates to the week ending the date given in parenthesis

Source : i) NCDEX, ii) Office of Economic Adviser, Ministry of Commerce and Industry, Govt. of India.

Prices of wheat C. Wheat Rs. Per $100 \mathrm{~kg}$

\begin{tabular}{|c|c|c|c|c|c|c|c|c|}
\hline \multirow{3}{*}{ Date } & \multirow{3}{*}{ Spot } & \multicolumn{6}{|c|}{ Spot and future prices at NCDEX } & \multirow{3}{*}{$\begin{array}{c}\text { WPI } \\
(93-94=100)^{*}\end{array}$} \\
\hline & & \multicolumn{6}{|c|}{ Futures closing prices for contract expiring on } & \\
\hline & & 20-03-07 & 20-04-07 & 18-05-07 & 20-06-07 & 20-07-07 & 20-08-07 & \\
\hline $27-02-07$ & 1039.85 & 955.20 & 882.20 & 886.40 & 904.80 & 918.80 & 935.00 & $231.8(24-02-07)$ \\
\hline $27-03-07$ & 1057.85 & & 1005.00 & 965.00 & 960.00 & 977.00 & 972.00 & $224.9(24-03-07)$ \\
\hline $27-04-07$ & 959.20 & & & 975.00 & 960.00 & 980.00 & 1001.20 & $217.2(28-04-07)$ \\
\hline $26-05-07$ & 917.55 & & & & 940.00 & 960.00 & 1001.20 & $216.6(26-05-07)$ \\
\hline $27-06-07$ & 975.00 & & & & & 985.00 & 1001.20 & $216.2(30-06-07)$ \\
\hline $27-07-07$ & 1052.45 & & & & & & 1041.00 & $223.5(26-07-07)$ \\
\hline 04-04-07 & 1023.95 & & & & & & 1041.40 & \\
\hline
\end{tabular}

Note: * Data relates to the week ending the date given in parenthesis

Source : i) NCDEX, ii) Office of Economic Adviser, Ministry of Commerce and Industry, Govt. of India.

\section{Analysis of Price Data}

4.11 Trend growth of WPI and its volatility for pre and post futures period of 21 agricultural commodities are presented in Table No.2B. Both monthly and weekly WPI data have been used for analysis and the rates have been annualized.

\section{Inflation}

4.12 Both monthly and weekly data show that the annual trend growth rate in prices was higher in the post-futures period in 14 commodities, viz. Chana, pepper, jeera, Urad Chillies, Wheat, Sugar, Tur, Raw Cotton, Rubber, Cardamom, Maize, Raw Jute and Rice; and lower in 7 commodities, viz. Soy oil, soy bean, Rape seed / Mustard seed, Potato, Turmeric, Castor seed, and Gur. The first set of commodities account for $48.2 \%$ of futures trading volume in agriculture and have a weight of $10.1 \%$ in the WPI. Corresponding figures for the second set are $21.3 \%$ and $1.7 \%$. The number of commodities in which inflation accelerated is double the number in which this decelerated, and their weights are also much higher in both futures trading and in the WPJ. Also, significantly, all sensitive commodities (i.e. food grains and sugar) recorded some acceleration in inflation after the start of futures trading. However, a revealing feature of this data is that of the 14 commodities in which acceleration took place in post-futures period, 10 had suffered negative inflation during the pre-futures period. It is possible in such cases that the acceleration in growth rate of WIN in these commodities is simply rebound and catch-up with the trend, which in turn could have been aided by more efficient price discovery. Similarly, of the 7 commodities in which WPI growth was lower post-futures, 6 had unusually high re-futures inflation at over $10 \%$. In these cases, too, it is possible that what is being observed is simply reversion to a more normal level of inflation. In both cases, there is the problem that the period during which futures markets have been in operation is much too short to discriminate adequately between the effect of opening up futures markets and what might simply be normal cyclical adjustments.

Nonetheless, some discrimination is possible if acceleration/deceleration is assessed requiring: (i) that the change in growth rate following introduction of futures was by some minimum amount (say 5 percentage points); and rule out cases of catch-up or reversion to normal inflation by also requiring: (ii) that, following the change, the growth rate averaged over both before and after was above/below some normal inflation range (say 0 to $5 \%$ ). By this criterion, no commodity shows deceleration and five, Chana, Chillies, Urad, Wheat and Rubber, show clearer evidence that inflation did accelerate following introduction of futures. These 5 commodities account for $32 \%$ of total value of futures trading in agricultural commodities but have a weight of only $1.9 \%$ in WPI. However, importantly, three of these five are food grains and include two of the four commodities that were de-listed in early 2007. An analysis was also carried out at macro rather than specific commodity level taking August 2004 as the cut-off point to divide pre-futures and post-futures periods. This is 
the middle month of the second quarter (July-Sept) of 2004-05 when, taking acceleration in total futures trading volume as the barometer, such trading picked up reasonably. After taking equal observations for both pre and post futures period, trend growth rates for both periods were calculated. This was done for (i) the weighted average WPI of the 21 selected commodities that have significant futures trading, (ii) all primary agricultural goods (i.e. Food and Non-Food Articles in the WPL Primary Articles Group) and (iii) the weighted composite index of the 87 processed and unprocessed agricultural commodities. This was also done for the three retail Consumer Price Indices, i.e. CPI-IW, CPI-AL and CPI-UNME.

The observed acceleration is quite high at 3 percentage points for CPI-AL, moderate at around 2 percentage points for CPI-IW and CPI-UNME, but low at less than 1 percentage point in case of all three indices derived from WPJ. Moreover, the composite WPI index of the 21 selected commodities with futures trading did not accelerate more than WPI for all agricultural commodities. Thus, although inflation clearly increased post-futures in some sensitive commodities that have higher weight in consumer prices indices, it is not possible to make any general claim that inflation accelerated more in commodities with futures trading. Similarly, although price volatility appears to have increased post-futures by these macro indices, this is less true of the composite index of these 21 traded commodities than of other indices.

\section{Volatility}

Price volatility (i.e. extent of price fluctuations around trend) is important because reduction in this, along with better price discovery, is the main benefit expected from futures trading. Indeed, NCDEX, the leading exchange for futures trade in agricultural commodities, has presented the Committee with analysis of daily spot price volatility of commodities for which it offers futures contracts, arguing that such volatility has reduced significantly. This is available for 19 of the 24 traded commodities selected earlier, and it may be seen that volatility was lower in 15 commodities during the post-futures period, higher in 3 commodities and remained same in one. If $25 \%$ change either way is taken as a confidence band, daily price volatility did not increase in any commodity and declined in 13 commodities, accounting for $41.9 \%$ of volume of agri-commodity futures trading and with $3.7 \%$ weight in WPI. These weights are however somewhat less than corresponding weights $(51.2 \%$ and $4.0 \%)$ for the remaining 6 commodities where changes in daily price volatility fall within the confidence band.

\section{Conclusion and Suggestions:}

From the above study it is evident that the correlation between the prices and the futures market trading is only marginal, if any. No purpose seemed to be served in burning the trading of agricultural products from the markets. The cause of inflation lies elsewhere and is caused by the supply demand volatilities and other reasons. However, there is a need for the market regulator to be ever cautious and keep a watch on manipulators. They can also expand the depth and breath of the market so that the farmers and processors play a more important role in the market, outplaying the manipulators. Greater integration of the spot and futures market is necessary so that it performs the functions of price discovery more effectively transparency and awareness is bound to make the futures market useful for all the stakeholders.

\section{References}

[1]. Lokare, S.M. (2006). "Commodity derivation and price risk management: a empirical study from India".

[2]. Nair C.K.G. (2005-06). "Commodity futures markets in India- ready for takeoff?".

[3]. Pravakar Saoo and Rajiv Kumar. "Impact of proposed commodity transaction tax on future trading in India", Working paper no.260, Report of ICRIER.

[4]. Sahadevan, K.G. (2007). "Derivates and risk management: a study of commodity future in India". 